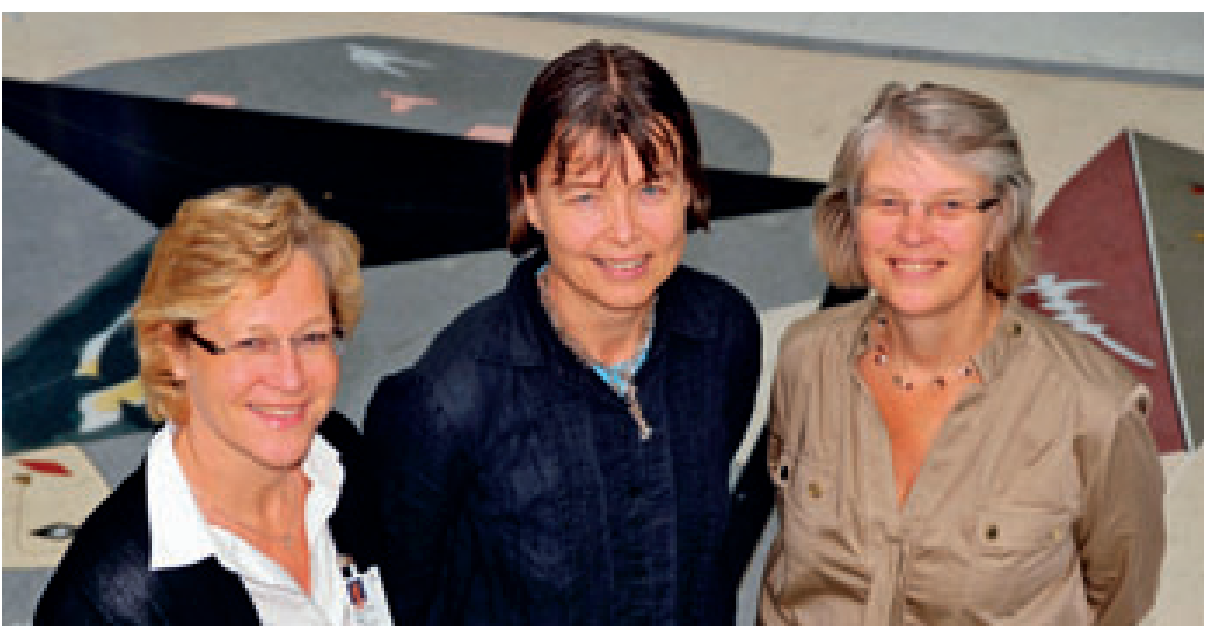

Fra venstre Hanne F. Harbo, Anne Spurkland og Elisabeth Gulowsen Celius. Foto Gunnar Lothe, Institutt for medisinske basalfag, Universitetet i Oslo

\title{
Nyoppdagede gener ved multippel sklerose
}

Genstudie viser at utviklingen av multippel sklerose er knyttet til

en rekke gener som har betydning for immunologiske funksjoner.

En internasjonal studie med bidrag fra Norge er nylig publisert i Nature (1). Studien omfattet 9722 pasienter med multippel sklerose og 17376 ubeslektede kontrollpersoner. Den genomvide assosiasjonsstudien identifiserte 29 nye genregioner som er forbundet med multippel sklerose samt bekreftet økt sykdomsrisiko knyttet til 23 genregioner som tidligere er beskrevet, blant annet HLA-gener. I tillegg påvises ytterligere fem nye genvarianter som høyst sannsynlig også er forbundet med risiko for multippel sklerose. Mange av genene som utpekes spiller en sentral rolle i immunsystemet, særlig for T-celler og interleukiner. Noen av genene er vist å ha betydning også for andre autoimmune sykdommer, slik som Crohns sykdom og type 1-diabetes. Dette indikerer at samme sykdomsprosesser kan forekomme ved flere typer autoimmune sykdommer. To av de påviste genvariantene er involvert i vitamin D-metabolismen, noe som kan indikerer en mulig sammenheng mellom genetiske faktorer og miljøfaktorer.

Professor Hanne F. Harbo ved Nevrologisk avdeling, Oslo universitetssykehus ledet det norske bidraget til studien, som er den hittil største genetiske studien av multippel sklerose, med bidrag fra nesten 250 forskere.

- I dette verdensomspennende forskningssamarbeidet har vi genscreenet 953 norske pasienter med multippel sklerose. Dette er dermed et av de største bidragene av pasientmateriale til denne omfattende studien. Forskningssamarbeidet i International MS Genetics Consortium og
Welcome Trust Case Control Consortium har vært avgjørende for å få frem den nye kunnskapen, sier Harbo.

\section{Internasjonalt forskersamarbeid} Professor Alastair Compston ved Universitetet i Cambridge, Storbritannia ledet studien sammen med professor Peter Donnelly, Universitetet i Oxford, Storbritannia. De norske medforfatterne er professor Hanne F. Harbo, seksjonsoverlege Elisabeth G. Celius, ph.d.-stipendiat Inger-Lise Mero, forskerne Åslaug R. Lorentzen og Cathrine Smestad, Oslo universitetssykehus, professor Anne Spurkland, Universitetet i Oslo, og professor Kjell-Morten Myhr ved Haukeland universitetssykehus. De arbeider videre med karakterisering av multippel skleroseassosierte genregioner og molekyler og hvordan disse påvirker det kliniske utrykket av sykdommen (2).

\section{Erlend Hem}

erlend.hem@medisin.uio.no

Tidsskriftet

\section{Litteratur}

1. International Multiple Sclerosis Genetics Consortium; Wellcome Trust Case Control Consortium. Genetic risk and a primary role for cell-mediated immune mechanisms in multiple sclerosis. Nature 2011: 476: 214-9.

2. Harbo HF, Lorentzen ÅR, Lie BA et al. Nytt genkart for multippel sklerose. Tidsskr Nor Legeforen 2011; 131: 2126-30
Ordforklaringer

Multippel sklerose er en av de vanligste nevrologiske sykdommene hos unge voksne. Man antar at om lag 7 000-8 000 personer er rammet i Norge.

Genomvid assosiasjonsstudie, ofte forkortet GWAS for «genome-wide association study». er en undersøkelse av genetisk variasjon gjennom hele genomet, designet for å identifisere genetisk assosiasjon med observerte fenotyper (f.eks. en bestemt sykdom). Slike studier krever normalt to grupper deltakere: personer med sykdom (pasienter) og tilsvarende personer uten sykdom (kontrollpersoner).

HLA: Human leucocyte antigen: HLA-molekylene er immunapparatets viktigste informasjonsmolekyler. De binder peptider og presenterer disse på celleoverflaten til T-lymfocyttene.

Genetisk risiko: Risiko for å utvikle sykdom betinget av genetiske faktorer.

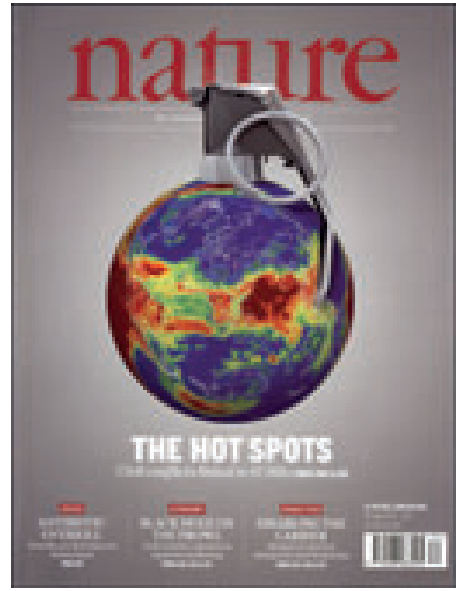

Artikkelen ble publisert 10.8. 2011 i Nature (www.nature.com), som er det høyest rangerte tidsskriftet innen tverrfaglig vitenskap (multidisciplinary sciences] 